\title{
KEABSAHAN ALAT BUKTI ELEKTRONIK PASCA PUTUSAN MAHKAMAH KONSTITUSI NO.20/PUU- XVI/2016 DALAM PRESPEKTIF CRIMINAL JUSTICE SYSTEMI
}

Oleh:

\section{Erma Lisnawati ${ }^{2}$}

\begin{abstract}
Indonesia is a state of law that upholds of human rights. In the state of law, there is a human rights protection by the state including the privacy of rights. It is referred judicial review of Act No. 11 of 2008 on Information and Electronic Transactions, of Article 5 Paragraph (2). To protect the privacy of recording and wiretapping conducted illegally. The Constitutional Court has been issued a ruling of the Constitutional Court No.20/PUU-XVI/2016 which imposes limits on how electronic evidence retrieval and also who is allowed to submit as an evidence in court.The court ruling was appropriate given the absence of norms regulating the procedures for the acquisition and delivery of electronic evidence. In a special lex such as criminal acts Corruption, Money Laundering and Terrorism Crime and Crime and Electronic Information only governs the kinds of electronic evidence alone, as well as the Code of Criminal Law.
\end{abstract}

\section{Keywords: Evidence of Electronic, the Constitutional Court, Criminal Justice System}

\begin{abstract}
Abstrak
Indonesia adalah negara hukum yang menjunjung tinggi hak asasi manusia.Dalam negara hukum, ada perlindungan hak asasi manusia oleh negara, termasuk hak pribadi. Undang-Undang Nomor 11 Tahun 2008 tentang Informasi dan Transaksi Elektronik, Pasal 5 ayat (2) telah diajukan yudisial review pada Mahkamah Konstitusi. Mahkamah Konstitusi telah mengeluarkan putusan Mahkamah Konstitusi Nomor 20/PUU-XVI/2016, yang memberikan batasan tentang cara pengambilan alat bukti elektronik yang diperkenankan untuk diajukan dalam proses persidangan. Hal ini, sudah tepat mengingat tidak adanya norma yang mengatur tentang cara perolehan alat bukti elektronik dan siapa yang berhak mengajukan alat bukti elektronik tersebut ke pengadilan. Dalam beberapa undang-undang khusus pedoman tentang alat bukti elektronik hanya mengatur mengenai tindak pidana khusus saja seperti pada Tindak Pidana Korupsi, Tindak Pidana Pencucian Uang, Tindak Pidana Terorisme dan Tindak Pidana Informasi dan Transaksi Elektronik.
\end{abstract}

\section{Kata kunci: Alat Bukti Elektronik, Mahkamah Konstitusi, Sistem Preadilan Pidana}

1 Artikel ini merupakan penelitian/karya ilmiah mahasiswi pada Program Studi Magister (S2) Ilmu Hukum Program Pasca Sarjana Universitas Udayana dan mengucapkan terimakasih kepada Dr. I Gede Artha, S.H., M.H., selaku Pembimbing I dan Dr. Dewa Made Suwartha, S.H., M.H., selaku Pembimbing II,

2 Penulis adalah mahasiswa Magister Ilmu Hukum Universitas Udayana, Denpasar, Bali, e-mail: erma. lisnawati@yahoo.com 


\section{PENDAHULUAN}

Perkembangan

teknologi

memberikan kemudahan pada manusia untukmenyelesaikanpekerjaanmenjadi lebih mudah dan lebih cepat.Selain itu perkembanganteknologijugamembuat wawasan semakin berkembang cepat dikarenakan informasi yang semakin mudah untuk didapatkan. Namun, perkembangan teknologi juga diikuti dengan perkembangan kejahatan yang semakin beraneka ragam.Berkembangnya kejahatan menuntut juga perkembangan hukum agar dapat memberikan rasa keadilan bagi masyarakat dan juga para pencari keadilan.

Rasa keadilan dapat terpenuhi bila sistem peradilan pidana dapat berjalan sebagaimana mestinya untuk memberikan perlindungan terhadap hak-hak para pencari keadilan. Sebagaimana Negara Indonesia adalah negara hukum yang tertuang di dalam konstitusi negara Indonesia yang terdapat pada Undang-Undang Dasar Negara Indonesia Tahun 1945 Pasal 1 ayat (3), "Negara Indonesia adalah negara hukum" Dalam negara hukum sistem kenegaraan diatur berdasarkan hukum yang berlaku yang berkeadilan dan disusun dalam suatu konstitusi. Semua akan tunduk pada hukum baik pemerintah maupun yang diperintah, sehingga semua orang akan mendapatkan perlakuan yang sama.

Seperti pendapat MunirFuadi, mengenai peranan hukum dalam negara hukum sebagai berikut; dalam negara hukum diperlukan pembatasan terhadap kekuasaan negara dan politik denganjelas, yang tidak dapat dilanggar oleh siapa pun.Dalam negara hukum, hukum memiliki peranan yang sangat penting dan berada di atas kekuasaan negara dan politik, kemudian muncul istilah pemerintah di bawah hukum (government under the law). ${ }^{3}$ Julius Sthal mengemukakan, konsep negara hukum (rechtstaat) mencakup empat elemen: 1. Perlindungan hak asasi manusia, 2. Pembagian kekuasaan, 3. Pemerintahan berdasarkan undangundang, 4. Peradilan Tata Usaha Negara. ${ }^{4}$

Perlindungan hak asasi manusia menempati posisi pertama dalam konsep negara hukum (rechtstaat), hal ini menunjukkan betapa hak asasi manusia harus diutamakan diatas segalanya untuk diberikan perlindungan oleh negara.Untuk memberikan perlindungan terhadap hak asasi manusia maka akan diutamakan penegakan hukum untuk mengantisipasi terhadap perlanggaran terhadap hak asasi manusia. Penegakan hukum memiliki tujuan untuk mewujudkan suatu keadilan. Dengan penegakan hukum maka hukum menjadi kenyataan yang ditaati oleh setiap masyarakat.Tanpa adanya penegakan hukum maka hukum hanya merupakan rumusan konseptual yang

3 MunirFuady, 2011, Teori Negara Hukum Modern Rechtstaat, PT. Refika Aditama, Bandung, hlm.1.

4 M. Hata Ali dan Amran Suadi, 2014, Sistem Pengawasan Badan Peradilan Indonesia, PT. Raja Grafindo Persada, Jakarta, hlm.57-58. 
tidak bernyali dan tidak memiliki kekuatan mengikat apapun.

Konsep penegakan hukum dibagi menjadi 3 (tiga) yaitu:

a. Total Enforcement Concept (konsep penegakan hukum yang bersifat total), yang menuntut agar semua nilai yang ada di belakang norma hukum tersebut ditegakkan tanpa terkecuali.

b. Full Enforcement Concept (konsep penegakan hukum yang bersifat penuh), yang menyadari bahwa konsep total perlu dibatasi dengan hukum acara dan sebagainya demi perlindungan kepentingan individu.

c. Actual Enforcement Concept (konsep penegakan hukum aktual), yang muncul setelah diyakini adanya diskresi dalam penegakan hukum karena keterbatasan-keterbatasan, baik yang berkaitan dengan sarana prasarana, kualitas sumber daya manusianya, kualitas perundangundangannya dan kurangnya partisipasi masyarakat. $^{5}$

Melihat konsep penegakan hukum diatas dapat diketahui bahwa poin dari penegakan hukum adalah meliputi penegakan hukum total yang menegakkan semua nilai yang terdapat pada norma hukum tanpa terkecuali

5 Muhammad Tahir Azhary, 2004, Negara Hukum (Suatu Study tentang PrinsipPrinsip Dilihat dari Segi Hukum Islam, Implementasinya Pada Periode Negara Madinah dan Masa Kini), Penerbit Bulan Bintang, Jakarta, hlm. 73-74. dan pada penegakan hukum yang bersifat penuh yaitu dari penegakan nilai yang terdapat pada norma hukum perlu adanya pembatasan dengan hukum acara yang bertujuan untuk perlindungan individu. Yang terakhir dalam penegakan hukum actual dijelaskan bahwa penegakan hukum ini akan muncul sebagai diskresi setelah adanya keterbatasan yang ada, baik prasarana maupun sumber daya manusia serta kualitas dari perundangundangan yang ada.

Pelaksanaan konsep penegakan hukum diatas akan terlaksana melalui Sistem Peradilan Pidana (Criminal Justice System) yang akan yang dilakukan melalui beberapa tahapan mulai dari penyidikan, penyelidikan sampai dengan peradilan oleh para penegak hukum yang bertujuan untuk memberikan perlindungan terhadap hak-hak para pencari keadilan. System Peradilan Pidana yang terpadu atau Integrated Justice System merupakan instrumen hukum pidana yang sangat penting dalam rangka penegakan hukum pidana materiil. ${ }^{6}$ Dalam rangka mencapai tujuan tersebut masingmasing para penegak hukum yang bertugas sebagai petugas hukum diantaranya adalah polisi, jaksa, dan hakim, yang meskipun tugasnya berbeda-beda tetapi mereka harus bekerja dalam satu kesatuan sistem. Artinya, dalam menjalankan tugasnya para petugas hukum tersebut harus

6 Sidik Sunaryo, 2004, Sistem Peradilan Pidana, Penerbit Universitas Muhamadiyah Malang, Malang, hlm.1. 
berhubungan secara fungsional.Hal ini dikarenakan dalam menjalankan suatu peradilan merupakan suatu sistem, yaitu dalam satu keseluruhan yang terangkai yang terdiri dari unsur-unsur yang saling terkaitdan terhubung secara fungsional diantaranya adalah sebagai penyelidik, penyidik, penuntut umum dan juga sebagai badan peradilan.

Herbert

L.Packer

memperkenalkan 2 (dua) model dari system peradilan pidana yaitu Due Process Model dan Crime Control Model, yang keduanya memiliki ciriciri sebagai berikut:

1. The crime control model tends to the emphasize this adversary aspect of the process. The due process model tends to make it central.

2. The value system that underlies the crime control model is based on the proposition that the repression of criminal conduct is by far the most important funcition to be performed by the criminal process. In order to achieve this high purpose, the criminal models requires that primary attention be paid to the efficiency with which the criminal process operates to screen suspects determine guilty and secure appropriate dispositions of person convicted of crime.

3. The presumption of guilty, as it operates in the crime control model. Is the operational expression of that confidences would be a mistake to think of the presumption of innocence that we are so used to thinking of as the polestar of the criminal process and that was well shall see occupies an important position in the due process model.

4. If the crime control model resembles an assembly line. The due process model look very much like an obstacles course. ${ }^{7}$

Packer melihat prioritas operasionalisasi dari dua sistem nilai yang berbeda pada due process model dan crime control model, yakni due process model adalah suatu negative model dan crime control model yaitu suatu affirmative model. Dengan negative model mengajarkan bahwa pembatasan atas kekuasaan dan cara penggunaan kekuasaan oleh aparat penegak hukum sangat perlu. Namun, dengan affirmative model eksistensi kekuasaan dan penggunaan kekuasaan justru secara maksimal. ${ }^{8}$

Tahapan proses peradilan pidana di Indonesia adalah berdasarkan ketentuan Kitab Undang-Undang Hukum Acara Pidana (KUHAP) dimulai dengan penyelidikan dan penyidikan, pra penuntutan,

7 Herbert L. Packer, 1968, The Limit of Criminal Sanction, Stanford University Press, California, hlm. 157-163.

8 Ruhut M.P. Panggaribuan, 2013, Hukum Acara Pidana Surat Resmi Advokat di Pengadilan, Penerbit Papas Sinar Sinanti, Jakarta, hlm. 21. 
penuntutan, pemeriksaan di pengadilan sampai dengan hukuman dijatuhkan oleh aparatur penegak hukum yang berwenang yang fungsinya masingmasing sudah ditentukan dalam Hukum Acara Pidana. Hal yang terpenting yang digunakan untuk memberikan hukuman pada para pelanggar hukum adalah diperlukan adanya alat bukti. Sebagaimana Pasal 184 dalam KUHAP Ayat (1), "alat bukti yang sah adalah: a. keterangan saksi, b. keterangan ahli, c. surat, d. petunjuk, e. keterangan terdakwa." Jelaslah sudah disebutkan bahwa ada 5 (lima) alat bukti yang sah yang dapat digunakan dalam peradilan pidana.

Pembuktian adalah suatu usaha untuk menunjukkan benar atau salahnya terdakwa dalam sidang pengadilan. ${ }^{9} \quad$ The term evidence denotes the materials which courts will consider in deciding dispute issue of fact. The law of evidence, there for, refers collectively to the rules governing the materials that courts will consider in deciding disputed factual issue. ${ }^{10}$ Dalam bahasa Inggris pembuktian adalah evidence. Evidence is any matter of fact which is furnished to a legal tribunal, otherwise than any reasoning or a reference to what is noticed without proof, as the basis of inference in ascertaining some other

9 M. Marwan dan Jimmy P., 2009, Kamus Hukum, penerbit Reality Publisher, Surabaya, hlm.496.

10 Kenneth J. Arenson dan MirkoBagaric, 2005 , Rules of Evidence in Australia Text and Cases, Lexis NexisButterwordths, Australia, hlm. xxxix. matter of act. ${ }^{11}$ Demikian pentingnya pembuktian untuk melindungi hakhak para pencari keadilan dalam proses peradilan pidana, karena dalam pembuktian akan diajukan beberapa alat bukti yang memiliki kaitan dengan peristiwa yang terjadi dapat menunjukkan kebenaran peristiwa pidana dan juga siapa pelakunya.

Untuk mengungkap suatu peristiwa pidana dalam peradilan pidana guna menemukan siapa pelaku dan bagaimana peristiwa itu terjadi maka diperlukan pembuktian. Sebagai mana kasus pidana No. Reg. Perkara: PDM-0362/ DENPA.KTB/ 04/ 2016. Kasus pidana tersebut adalah pengeroyokan yang dilakukan oleh 4 (empat) orang pelaku dengan satu korban.Korban sendiri tidak dapat mengenali pelaku.Dan dari beberapa saksi yang dihadirkan dalam persidangan dibawah sumpah telah mengakui bahwa tidak melihat kejadian secara langsung, namun hanya mengetahui kejadian setelah menonton rekaman CCTV yang ada di tempat kejadian peristiwa pengeroyokan tersebut. Namun dalam CCTV tersebut salah satu pelaku mengakui tidak ikut melakukan pengeroyokan hanya berada ditempat kejadian tersebut karena sedang berkumpul dengan teman-temanya sebelum dan saat terjadi pengeroyokan. Pada gambar CCTV tersebut terdapat adegan atau gambar 3 (tiga) orang pelaku sedang

11 Bryan A. Garner, 2009, Black's Law Dictionary, Ninth Edition, West Publishing Co, Texas, hlm.635. 
melakukan pengeroyokan. Namun, tidak ditemukan gerakan salah satu pelaku tersebut sedang melakukan pengeroyokan, dia hanya terlihat berlari melintasi korban dalam gambar tersebut. Jaksa Penutut Umum mengajukan Dakwaan Alternatif yaitu: Pertama, Terdakwa diancam pidana sesuai dengan ketentuan Pasal 170 ayat (2) ke 1 KUHP; Kedua, Terdakwa diancam pidana sesuai dengan ketentuan Pasal 351 ayat (1) Jo Pasal 55 ayat (1) ke 1 KUHP

Tim kuasa hukum dari para pelaku pun mengajukan nota pembelaan (pledoi) atas dakwaan Jaksa Penuntut Umum, dengan No. 16/KLO/ PIDANA/VI/2016, yang pada intinya mengajukan keberatan atas alat bukti rekaman CCTV yang diajukan karena keabsahannya yang tidak masuk dalam Pasal184KUHAP, mengingatKUHAP tidak mengatur alat bukti CCTV dan juga tidak disertai keterangan ahli dalam proses persidangan. Karena kasus pengeroyokan ini termasuk dalam kejahatan konvensional bukan merupakan tindak pidana khusus dimana telah diatur mengenai alat bukti elektronik dalam beberapa tindak pidana khusus seperti tindak pidana korupsi, tindak pidana terorisme dan juga tindak pidana pencucian uang.

Nota pembelaan sudah diajukan, akan tetapi Jaksa Penuntut Umum tetap dengan tuntutan sesuai dengan dakwaan. Jaksa Penuntut Umum memberikan tuntutan Pasal 351 ayat (1), "Penganiayaan diancam dengan pidana penjara paling lama 2 (dua) tahun 8 (delapan) bulan atau pidana denda paling banyak 4.500, - (empat ribu lima ratus rupiah)". Jo Pasal 55 ayat (1) ke-1 KUHP, "Mereka yang melakukan,yangmenyuruhmelakukan, dan yang turut serta melakukan perbuatan", pada keempat pelaku tersebut dengan tuntutan 1 (satu) tahun penjara, dengan alat bukti 1 (satu) unit flash disk yang berisi rekaman CCTV kejadian peristiwa pengeroyokan dan 3(tiga) orang saksi ditambah satu saksi korban pengeroyokan tersebut. Majelis Hakim menjatuhkan vonis 10 (sepuluh) bulan penjara.

Tata cara pembuktian berpedoman pada Pasal 183 dan Pasal 184 KUHAP dimana tidak menyebutkan alat bukti elektronik sebagai alat bukti yang sah. Alat bukti yang diatur di luar KUHAP yang menyebutkan bahwa alat bukti elektronik adalah sah sebagai alat bukti terdapat pada Undang-Undang Nomor 20 Tahun 2001 tentang Pemberantasan Tindak Pidana Korupsi, UndangUndang Nomor 15 Tahun 2002 tentang Tindak Pidana Pencucian Uang, Undang-Undang Nomor 15 Tahun 2003 tentang Pemberantasan Tindak Pidana Terorisme, dan UndangUndang Nomor 11 Tahun 2008 tentang Informasi dan Transaksi Elektronik.

Alat bukti yang diatur di luar KUHAP hanya untuk tindak pidana khusus saja atau lex specialist. Pasca keluarnya Putusan Mahkamah Konstitusi No.20/PUU-XVI/2016 
menimbulkan pro dan kontra dalam penggunaan alat bukti elektronik sebagai alat bukti yang sah di persidangan. Putusan Mahkamah Konstitusi tersebut menyatakan "alat bukti dilakukan dalam rangka penegakan hukum atas permintaan kepolisian, kejaksaan dan/atau institusi penegak hukum lainnya yang ditetapkan berdasarkan undangundang...”. Ada pendapat yang menyatakan alat bukti tidak sah digunakan di pengadilan karena bukan dilakukan oleh penegak hukum,ada juga yang berpendapat tetap sah karena adanya undang-undang yang mengatur secara lex specialist.

Berdasarkan uraian pendahuluan di atas telah ditemukan 2 (dua) rumusan masalah dalam penelitian ini, diantaranya adalah sebagai berikut: Pertama, apakah ada perbedaan keabsahan penggunaan alat bukti elektronik dalam sistem peradilan pidana (criminal justice system) yang terdapat pada kejahatan konvensional (conventional crime) dan tindak kejahatan khusus (extra ordinary crime)? Kedua, bagaimanakah kedudukan alat bukti elektronik dalam sistem peradilan pidana (criminal justice system) pasca Putusan Mahkamah Konstitusi Nomor 20/ PUU-XVI/2016?

Orisinalitas penelitian pada penulisan ini adalah bahwa penulis tidak menemukan kesamaan topik dan permasalahan pada tulisan ini dengan artikel-artikel lain yang sudah ada. Namun, ada beberapa kemiripan dengan artikel-artikel lain yang penulis sampaikan di sini sebagai bahan referensi saja, diantaranya adalah pertama, artikel dengan judul, "Alat Bukti Elektronik Sebagai Alat Bukti di Persidangan dalam Hukum Acara Pidana", dengan permasalahan, yang pertama adalah mengenai "Bagaimanakah pertimbangan hakim mengenai digunakannya alat bukti elektronik di persidangan? Kedua, apakah konsekuensi putusan hukum dari hakim mengenaidigunakannyaalat bukti elektronik di pengadilan?". ${ }^{12}$

Artikel kedua sebagai bahan referensi adalah "Dokumen Elektronik Sebagai Alat Bukti Pada pembuktian di Pengadilan", dengan permasalahan pertama adalah sebagai berikut, "Bagaimanakah prinsip pembuktian setelah berlakunya undang-undang Informasi dan Transaksi Elektronik?. Kedua, bagaimana keabsahan dan kekuatan pembuktian atas dokumen elektronik sebagai alat bukti di pengadilan setelah berlakunya undangundang Informasi dan Transaksi Elektronik?". ${ }^{13}$

Artikel ketiga sebagai bahan referensi adalah "Legalitas Personal Chat Pada Sosial Media Sebagai

12 Jodi. S., dan EdyHerdianto, Alat Bukti Elektronik Sebagai Alat Bukti di Persidangan dalam Hukum AcaraPidana,jurnal.hukum. uns.ac.id/index.php/verstek/article/view/703, diakses pada Tahun 2015

13 Johan Wahyudi, Dokumen elektronik Sebagai Alat Bukti Papa Pembuktian di Pengadilan, Jurnal Fakultas Hukum Universitas Airlangga Surabaya, Volume XVII No. 2 Tahun 2012 Edisi Mei. 
Alat Bukti di Pengadilan". Dengan permasalahan sebagai berikut, "Bagaimanakah legalitas personal chat pada social media sebagai alat bukti di muka pengadilan?"14

Ketiga artikel tersebut memiliki kesamaan dengan artikel ini antara lain sama-sama mengulas mengenai bukti elektronik sebagai alat bukti yang digunakan di persidangan. Namun, ada banyak perbedaan dalam penelitiannya, diantaranya artikel ini meneliti mengenai perbedaan keabsahan alat bukti elektronik yang digunakan di persidangan pada kejahatan konvensional dengan tindak pidana khusus yang tidak diulas dalam artikel-artikel yang dijadikan bahan referensi di atas. Perbedaan yang lain pada artikel ini dengan artikel-artikel yang lain adalah cara perolehan dan penyampaian alat bukti elektronik yang digunakan di persidangan dengan cara unlawfull legal evidence yang tidak diteliti pada artikel-artikel yang lain.

Adapun tujuan dilakukannya penelitian ini antara lain, adalah: Pertama, untuk mengetahui dan memahami perbedaan keabsahan penggunaan alatbuktielektronik dalam sistem peradilan pidana (criminal justice system) yang terdapat pada kejahatan konvensional (conventional crime) dan tindak kejahatan khusus (extra ordinary crime). Kedua, untuk

14 I Putu KrisnaAdhi dan Made Nurmawati, Legalitas Personal Chat Pada Sosial Media Sebagai Alat Bukti di Pengadilan, Fakultas Hukum Universitas Udayana,ojs. unud.ac.id/index.php/kerthawicara/article/ view/21305/14077, diakses pada Tahun 2016 . mengetahui dan memahami kedudukan alat bukti elektronik dalam sistem peradilan pidana (criminal justice system) pasca Putusan Mahkamah Konstitusi No.20/PUU-XVI/2016.

\section{METODE PENELITIAN}

Penelitian ini adalah penelitian hukum normatif, yang mengkaji tentang asas hukum, sistematika hukum, mengkaji perbandinganperbandingan hukum serta sejarah hukum. ${ }^{15}$ Penelitian hukum normatif mendasarkan pada bahan hukum primer dan sekunder.

III. HASIL DAN PEMBAHASAN

3.1 Perbedaan keabsahan penggunaan alat bukti elektronik dalam sistem peradilan pidana (criminal justice system) yang terdapat pada kejahatan konvensional (conventional crime) dan tindak kejahatan khusus (extra ordinary crime).

Berkembangnya teknologi telah diikuti dengan perkembangan kejahatan.Karena kejahatan seperti memiliki moto "amati, tiru, modifikasi" (ATM). Jadi, bila diperhatikan kejahatannya masih sama yaitu kejahatan konvensional namun caranya yang sudah berkembang. Untuk itulah hukum juga harus mengikuti perkembangan teknologi dan masyarakat yang semakin dinamis,

15 Soerjono S. \& Sri M., 2012, Penelitian Hukum Normatif.Suatu Tinjauan Singkat, Cet. Ke-14, PT. raja Grafindo, Jakarta, hlm. 14 
sehingga tidak akan ada suatu kejahatan yang akan lolos dari jerat hukum. Hal ini dimaksudkan untuk memberikan perlindungan dan rasa keadilan bagi masyarakat khususnya para pencari keadilan.

Pada peristiwa pengeroyokan yang dicontohkan pada latar belakang diatas yaitu kasus pidana No. Reg. Perkara: PDM-0362/ DENPA. KTB/ 04/ 2016 dimana pengeroyokan yang dilakukan oleh 4 (empat) orang pelaku terhadap 1 (satu) korban.Jaksa Penuntut Umum menuntut keempat pelaku dengan hukuman 1 (satu) tahun penjara, kemudian Majelis Hakim memutus dengan 10 (sepuluh) bulan penjara lebih ringan dari tuntutan Jaksa Penuntut Umum.Namun yang menjadi masalah adalah salah satu pelaku pengeroyokan tersebut mengakui tidak ikut dalam melakukan pengeroyokan, dan tidak ada satu pun saksi yang dihadirkan oleh Jaksa Penuntut Umumyang melihat kejadian secara langsung. Saksi hanya menyaksikan rekaman CCTV di tempat kejadian, dari rekaman CCTV yang ditunjukkan di dalam persidangan tidak ada adegan yang menunjukkan salah satu pelaku tersebut melakukan atau ikut melakukan pengeroyokan, dalam rekaman CCTV tersebut salah satu pelaku tersebut hanya berlari melintasi korban.

Diperlukan pembuktian dalam perkara ini dikarenakan hak dari terdakwa harus dilindungi. Sebagaimana Tujuan Hukum Acara
Pidana yang terdapat pada pedoman UU No. 8 Tahun 1981 tentang Hukum Acara Pidana adalah untuk mencari dan mendapatkan kebenaran materiil, ialah kebenaran yang selengkaplengkapnya dari suatu perkara pidana dengan menerapkan hukum pidana secara jujur dan tepat, dengan tujuan untuk mencari siapakah pelaku yang dapat didakwakan selanjutnya meminta dan putusan dari pengadilan guna menentukan apakah terbukti bahwa suatu tindak pidana telah dilakukan dan apakah orang yang didakwakan itu dapat dipersalahkan pada tahap persidangan perkara tersebut. ${ }^{16}$

Pembuktian

dilakukan sebagaimana Pasal 6 ayat (2) UndangUndang Nomor 48 Tahun 2009 tentang KekuasaanKehakiman, "Tidakseorang pun dapat dijatuhi pidana kecuali apabila pengadilan karena alat bukti yang sah menurut undang-undang, mendapat keyakinan bahwa seorang yang dianggap dapat bertanggung jawab, telah bersalah atas perbuatan yang didakwakan atas dirinya". Untuk membuktikan seseorang bersalah harus melalui proses peradilan sebagaimana asas equality before the law, setiap orang memiliki hak yang sama di depan hukum. Jadi sebelum ada vonis hakim maka seorang terdakwa pun belum dianggap bersalah melakukan peristiwa pidana.Hal ini sejalan dengan due proses of law. Sebagaimana sistem peradilan pidana/criminal justice

16 Andi Hamzah, 2008, Hukum Acara Pidana di Indonesia, Sinar grafika, Jakarta, hlm.7-8. 
system yang diperkenalkan oleh Herbet L. Packer, dalam Eddy O.S. Hiariej, yakni dalam due process model terdapat karakteristik menolak efisiensi, dengan mengutamakan kualitas dan presumption of innocent, yang bertujuan untuk menghindari hukuman terhadap orang yang tidak bersalah. ${ }^{17}$

Tindak pidana konvensional mengacu pada KUHAP mengenai pedoman pembuktian dalam proses peradilan pidana. Dalam sistem peradilan pidana termasuk di Indonesia dianut negatiefwettelijkbewijstheorie, yaitu dasar pembuktian menurut keyakinan hakimyang timbul dari alat bukti dalam undang-undang secara negatif. ${ }^{18}$ Pasal 183 KUHAP menyebutkan, "Hakim tidak boleh menjatuhkan pidana kepada seorang kecuali apabila dengan sekurangkurangnya dua alat bukti yang sah ia memperoleh keyakinan bahwa suatu tindak pidana benar-benar terjadi dan bahwa terdakwa lah yang bersalah melakukannya". Kemudian pada Pasal 184 KUHAP menyatakan bahwa, "Alat bukti yang sah ialah: a. Keterangan Saksi; b. Keterangan Ahli; c. Surat; d. Petunjuk; e. Keterangan Terdakwa". Sangat jelas sekali ada 5 (lima) macam alat bukti yang sah yang dapat digunakan dalam proses peradilan yang di dalamnya tidak menyebutkan CCTV sebagai alat bukti yang sah.

17 Eddy O.S. Hiariej, 2012, Teori dan Hukum Pembuktian, Penerbit Erlangga, Jakarta, hlm.30.

18 Ibid.
Pedoman pembuktian juga terdapat dalam Ketentuan Pasal 5 ayat (2) Undang-Undang Nomor 11 Tahun 2008 tentang Informasi dan Transaksi elektronik yang menegaskan bawa: "Informasi elektronik dan/atau dokumen elektronik dan/atau hasil cetakannya sebagaimana dimaksud pada ayat sebelumnya, merupakan perluasan dari alat bukti yang sah sesuai dengan hukum acara yang berlaku di Indonesia". Dengan demikian CCTV yang dipergunakan sebagai alat bukti pada persidangan adalah sah.

Beberapa pedoman mengenai alat bukti juga terdapat pada Undangundang Khusus di luar KUHAP, yang memberikan kedudukan sah alat bukti elektronik pada persidangan diantaranya adalah: Pertama, ketentuan Pasal 26 a, Undang-Undang Nomor 20 Tahun 2001 tentang Pemberantasan Tindak Pidana Korupsi, yang menyebutkan, "Alat bukti yang disimpan secara elektronik juga dapat dijadikan alat bukti yang sah dalam kasus tindak pidana korupsi”.

Kedua, ketentuan Pasal 38 huruf $\mathrm{b}$, Undang-Undang Nomor 15 Tahun 2002 tentang Tindak Pidana Pencucian Uang, "Alat bukti Tindak Pidana Pencucian uang berupa: a. alat bukti sebagaimana dimaksud dalam hukum acara pidana, b. alat bukti berupa informasi yang diucapkan, dikirimkan, diterima/atau disimpan secara elektronik dengan alat optic atau yang serupa itu, dan c. dokumen sebagaimana dimaksud Pasal 1 
angka 7. Dalam Pasal 1Angka 7 menyebutkan: "Dokumen adalah data, rekaman atau informasi yang dapat dilihat, dibaca, dan/atau didengar, yang dapat dikeluarkan dengan atau tanpa bantuan suatu sarana, baik yang tertuang di atas kertas, benda fisik ataupun selain kertas, atau yang terekam secara elektronik termasuk tetapi tidak terbatas pada; a. tulisan, surat atau gambar; b. peta, rancangan, foto, atau sejenisnya; c. huruf, tanda, angka, simbol, atau perforasi, yang memiliki makna atau dapat dipahami oleh orang yang mampu membaca atau memahaminya".

Ketiga, ketentuan dalam Pasal 27 huruf b Undang-Undang Nomor 15 Tahun 2003 tentang Pemberantasan Tindak Pidana Terorisme, "Alat bukti pemeriksaan tindak pidana terorisme meliputi: a. Alat bukti sebagaimana dimaksud dalam hukum acara pidana; b. Alat bukti lain berupa informasi yang diucapkan, dikirim, diterima, atau disimpan secara elektronik dengan alat optic atau yang serupa dengan itu; dan c. 1. tulisan, surat atau gambar; 2. peta, rancangan, foto, atau sejenisnya; 3. huruf, tanda, angka, symbol, atau perforasi, yang memiliki makna atau dapat dipahami oleh orang yang mampu membaca atau memahaminya".

Pedoman penggunaan alat bukti elektronik yang terdapat pada undangundang khusus di luar KUHAP adalah untuk tindak pidana khusus dan digunakan pada kejahatan tertentu seperti tindak pidana korupsi, tindak pidana pencucian uang dan terorisme saja, undang-undang tersebut digunakan sebagai lexspecialis derogate legigenerali.

\subsection{Kedudukan alat bukti elektronik dalam sistem peradilan pidana (criminal justice system) pasca Putusan Mahkamah Konstitusi Nomor 20/PUU-XVI/2016.}

Terdapat pro dan kontra pasca putusan Mahkamah Konstitusi No.20/ PUU-XVI/2016 yang menyebutkan bahwa alat bukti dilakukan dalam rangka penegakan hukum atas permintaan kepolisian, kejaksaan dan/atau institusi penegak hukum lainnya yang ditetapkan berdasarkan undang-undang...”. Beberapa orang berpendapat bahwaalatbuktielektronik tidak bisa lagi digunakan dalam proses peradilan manakala bukan diambil oleh kepolisian, kejaksaan dan/atau institusi penegak hukum, dan sangat menyayangkan putusan Mahkamah Konstitusi tersebut, namun ada beberapa orang yang berpendapat bahwa alat bukti elektronik masih bisa digunakan berdasarkan undangundang khusus yang sudah di uraian diatas.

Jimly Assiddiiqie, dalam Maruarar, menguraikan bahwa dalam konteks ketatanegaraan, Mahkamah Konstitusi dikonstruksikan sebagai pengawal konstitusi yang berfungsi menegakkan keadilan konstitusional di tengah kehidupan masyarakat. 
Mahkamah Konstitusi bertugas mendorong dan menjamin agar konstitusi dihormati dan dilaksanakan oleh semua komponen negara secara konsisten dan bertanggungjawab.Di tengah kelemahan sistem konstitusi yang ada, Mahkamah Konstitusi berperan sebagai penafsir agar spirit konstitusi selalu hidup dan mewarnai keberlangsungan bernegara dan bermasyarakat. ${ }^{19}$

Uraian diatas dibenarkan dengan melihat Undang-Undang Nomor 24 Tahun 2003 tentang Mahkamah Konstitusi, Pasal 10 ayat (1) menyebutkan, "Mahkamah Konstitusi berwenang mengadili pada tingkat pertama dan terakhir yang putusannya bersifat final; huruf a. "Menguji undang-undang terhadap Undang-Undang Dasar Negara Republik Indonesia Tahun 1945". Mahkamah Konstitusi berwenang mengadili perkara konstitusi dalam tingkat pertama dan terakhir yang putusannya bersifat final.Itu berarti bahwa putusan Mahkamah Konstitusi langsung memperoleh kekuatan hukum tetap sejak diucapkan dan tidak ada upaya hukum yang dapat ditempuh. Putusan Mahkamah Konstitusi berlaku sebagai hukum sebagaimana hukum yang diciptakan pembuat undang-undang. Hakim Mahkamah Konstitusi dikatakan sebagai negative legislator yang putusan nya bersifat orgaomnes, yang ditujukan pada

19 MaruararSiahaan, 2015, Hukum Acara Mahkamah Konstitusi Republik Indonesia, Sinar Grafika, Jakarta, hlm.8. semua orang. Kekuatan mengikat putusan Mahkamah Konstitusi tersebut mengikat semua orang, lembaga negara dan badan hukum dalam wilayah Republik Indonesia. ${ }^{20}$

Mengingat putusan Mahkamah Konstitusi yang bersifat final dan mengikat bagi semua orang maka perlu memahami putusan tersebut sehingga tidak terjadi multitafsir terhadap putusan tersebut. Pada putusan Mahkamah Konstitusi No. 20/ PUU-XVI/2016 tanggal 7 September 2016, merupakan uji materi Pasal 5 ayat (1) dan ayat (2) dan Pasal 44 huruf b Undang-Undang Nomor 8 Tahun 2011 tentang Informasi dan Transaksi Elektronik, dan Pasal 26 a Undang-Undang Nomor 20 Tahun 2011 tentang Tindak Pidana Korupsi, khususnyafrasa "Informasi elektronik dan/ataudokumenelektronik.Dianggap melanggar hak pribadi pemohon yaitu Pasal 28D ayat (1) yaitu, hak atas jaminan perlindungan diri pribadi (hak privasi) serta hak atas rasa aman dari tindakan perekaman yang tidak sah dan sewenang-wenang sebagaimana Pasal 28G ayat (1) Undang-Undang Dasar Negara Republik Indonesia Tahun 1945.

Amar putusan ya Mahkamah Konstitusi mengabulkan, Frasa "informasi elektronik dan/atau dokumen elektronik sebagai alat bukti dilakukan dalam rangka penegakan hukum atas permintaan kepolisian, kejaksaan, dan/atau institusi penegak

20 Ibid, 
hukum lainnya yang ditetapkan berdasarkan undang-undang....”. Dari uraian diatas penulis memaknai bahwa informasi elektronik dan/atau dokumen elektronik dapat diajukan sebagai barang bukti atas permintaan kepolisian, kejaksaan, dan/atauinstitusi penegak hukum lainnya, adalah adanya pembatasan siapa saja yang boleh mengajukan informasi elektronik dan/ atau dokumen elektronik sebagai alat bukti, dan tidak semua orang dapat mengajukan informasi elektronik dan/atau dokumen elektronik sebagai alat bukti bila tidak ada permintaan dari kepolisian, kejaksaan, dan/atau institusi penegak hukum lainnya.

Mengingat pengajuan uji materi tersebut dikarenakan pemohon merasa dirugikan kepentingan pribadinya. Sehingga Mahkamah Konstitusi memberikan perlindungan hak pribadi seseorang untuk tidak dilanggar sebagaimana Mahkamah Konstitusi berfungsi antara lain sebagai "guardian" dari "constitutional right" bagi setiap warga Negara Republik Indonesia. Mahkamah Konstitusi juga merupakan badan yudisial yang bertugas menjaga hak asasi manusia sebagai bentuk perlindungan atas hak konstitusional dan hak hukum setiap warga negara. Maka alat bukti elektronik masih dapat digunakan sepanjang penggunaannya diajukan atas permintaan para penegak hukum. Hal ini sesuai dengan parameter pembuktian yaitu bevijsvoering.

$$
\text { Bevijsvoering, diartikan }
$$
sebagaimana menyampaikan alat-alat bukti kepada hakim di pengadilan. Bagi negara-negara yang cenderung menggunakan due process model dalam sistem peradilan pidananya, perihal bevijsvoerinini cukup mendapat perhatian. Dalam due process model negara begitu menjunjung tinggi hak asasi manusia (hak-hak tersangka) sehingga acapkali seorang tersangka dibebaskan oleh pengadilan dalam pemeriksaan pra peradilan lantaran alat bukti diperoleh dengan cara yang tidak sah atau yang disebut dengan istilah unlawfull legalevidence. ${ }^{21}$ Herbert L. Packer, dalam Lilik Mulyadi, menyatakan bahwa suatu bukti illegal acquired evidence (perolehan bukti secara tidak sah) tidak patut dijadikan sebagai alat bukti di persidangan. ${ }^{22}$

Pembuktian dilihat dari perspektif hukum acara pidana, yakni ketentuan yang membatasi sidang pengadilan dalam usaha mencari dan mempertahankan kebenaran, baik oleh hakim, penuntut umum, terdakwa maupun penasihat hukum, semuanya terikat pada ketentuan dan tatacara, serta penilaian alat bukti yang ditentukan oleh undang-undang. Tidak dibenarkan untuk melakukan tindakan yang leluasa sendiri dalam menilai alat bukti dan tidak boleh bertentangan dengan undang-undang.Terdakwa tidak boleh mempertahankan sesuatu yang dianggap benar di luar ketentuan yang ditentukan oleh undang-undang. ${ }^{23}$

21 Eddy O.S. Hiariej, Op Cit, hlm.20.

22 LilikMulyadi, 2007, Pembalikan Beban Pembuktian Tindak Pidana Korupsi, Alumni, Bandung, hlm.84.

23 Eddy O.S. Hiariej, Op Cit, hlm. 8. 
Sehingga pembuktian perlu dilakukan untuk menghindari sistem peradilan pidana/criminal justice system dengan menggunakan crime control model, yaitu yang memiliki karakteristik efisiensi, mengutamakan kecepatan dan presumption of guilty sehingga tingkah laku kriminal harus segera ditindak dan si tersangka dibiarkan sampai dia sendiri melakukan perlawanan. Model ini di ibaratkan seperti sebuah bola yang sedang digelinding dan tanpa penghalang. ${ }^{24}$

Kaitannya dengan pembuktian, due process of law memiliki hubungan erat dengan masalah bewijsvoering, yaitu caramemperoleh, mengumpulkan dan menyampaikan bukti sampai ke pengadilan. Tidak jarang hal-hal yang bersifat formalistik mengesampingkan kebenaran materiil.Di negara yang menjunjung tinggi due process of law, dalam hukum acaranya perlindungan dari individu dari tindakan sewenangwenang aparat negara mendapat perhatian khusus. ${ }^{25}$

Tindakan untuk memperoleh barang bukti dengan cara yang melanggar hukum merupakan bentuk dari penyesatan sistem peradilan pidana. Di Indonesia belum ada norma yang mengatur tentang cara untuk mendapatkan dan menghadirkan alat bukti dalam proses peradilan pidana, sehingga keputusan Mahkamah Konstitusi No.20/PUU-XVI/2016 sudah sangat tepat, dalam hal ini bukan alat bukti elektronik yang tidak boleh diajukan dalam proses peradilan bila tidak diambil oleh para penegak hukum, namun cara perolehan dan pengajuannya yang tidak diperbolehkan sebagai alat bukti, bila alat bukti elektronik tersebut tidak diajukan oleh para penegak hukum untuk penegakan hukum dalam proses peradilan pidana. Sehingga adanya pembatasan mengenai bagaimana alat bukti elektronik diperoleh dan bagi siapa yang boleh mengajukan alat bukti elektronik sebagai alat bukti pada proses peradilan pidana. Tujuannya adalah untuk melindungi privacy seseorang warga negara sebagaimana hak asasi yang dilindungi oleh konstitusi. Bila perolehan alat bukti elektronik tersebut melanggar hak asasi dan privasi seseorang hal ini tidak dibenarkan karena merupakan unlawfull legalevidence. Dengan demikian akan tercapai apa yang dikemukakan oleh Jeremy Bentham, the greatest happiness for the greatest number of people, kebahagiaan yang terbesar harus untuk jumlah rakyat yang terbesar. Demikianlah konstitusi melindung hak-hak dari masyarakat.

Tujuan hukum dan wujud keadilan menurut Jeremy Bentham adalah untuk mewujudkan the greatest happiness for the greatest number of people, kebahagiaan yang sebesar-besarnya untuk sebanyakbanyaknya orang. Tujuan perundangundangan menurutnya adalah untuk menghasilkan kebahagiaan bagi 
masyarakat. ${ }^{26}$ Baginya, kebaikanadalah kebahagiaan dan kejahatan adalah kesusahan.Ada keterkaitan yang erat antara kebaikan dan kejahatan dan kesusahan. Tugas hukum adalah memelihara kebaikan dan mencegah kejahatan.Tegasnya memelihara kegunaan. ${ }^{27}$

\section{Kegunaan} merupakan

kemanfaatan yang terdapat pada teori utilitiarianisme yang dikembangkan oleh Jeremy Bentham dan muridnya, John stuard Mill. Teori ini disebut juga dengan the greatest happiness theory. Menurut teori ini suatu perbuatan adalah baik jika membawa manfaat, tapimanfaattersebutharus menyangkut bukan hanya satu atau dua orang melainkan masyarakat sebagai keselu ruhan. ${ }^{28}$ Utilitiarianisme adalah aliran yang meletakan kemanfaatan sebagai tujuan utama hukum.Kemanfaatan diartikan sebagai kebahagiaan.Jadi baik buruk atau adil tidaknya suatu hukum, bergantung kepada apakah hukum itu memberikan kebahagiaan kepada manusia atau tidak. $^{29}$ Demikianlah suatu undang-undang dibuat harus memberikan manfaat untuk kebahagiaan masyarakat dan tidak merugikan sebagaimana apabila suatu perundang-undangan melanggar

26 Teguh Prasetyo dan Abdul Halim Barkatullah, 2014, Fisafat, Teori, dan Ilmu Hukum, PT Raja Grafindo Persada, Jakarta, hlm.112.

27 Sukarno aburaera, dkk, 2014, Filsafat Hukum Teori dan Praktik, Kencana Prenada Group, Jakarta, hlm.112.

28 ZainalAsikin, 2013, Mengenal Filsafat Hukum, Pustaka Reka Cipta, Bandung, hlm.117.

29 Darji Darmodiharjo dan Shidartha, 2006, Pokok-Pokok Filsafat Hukum, Perbit PT Gramedia, Jakarta, hlm.117. hak asasi maka sudah sepatutnya diajukan untuk dilakukan judicial review terhadap Undang-Undang Dasar Negara Republik Indonesia Tahun 1945 sebagaimana hasil dari putusan Mahkamah Konstitusi No.20/ PUU-XVI/2016, yang memberikan perlindungan pada privacy individu dari perekaman atau penyadapan liar, sehingga diberikan pembatasan cara memperoleh dan pengajuan alat bukti elektronik dalam proses persidangan, hal ini sesuai dengan due process of law.

\section{KESIMPULAN}

Setelah menguraikan pendahuluan kemudian menemukan permasalahan dan juga melalui pembahasan diatas, sampailah penulis pada kesimpulan, yaitu:

1. Ada perbedaan keabsahan penggunaan alat bukti elektronik dalam sistem peradilan pidana (criminal justice system) yang terdapat pada kejahatan konvensional (conventional crime) dan tindak kejahatan khusus (extra ordinary crime). Dalam kejahatan konvensional KUHAP tidak mengatur mengenai alat bukti elektronik sebagaimana yang terdapat pada undang-undang khusus seperti Tindak Pidana Korupsi, Tindak Pidana Pencucian Uang dan Tindak Pidana Terorisme. Untuk saat ini pada kejahatan konvensional yang digunakan 
landasan yuridis adalah Undangundang Informasi dan Transaksi elektronik.

2. Kedudukan alat bukti elektronik dalam sistem peradilan pidana (criminal justice system) pasca Putusan Mahkamah Konstitusi No. 20/PUU-XVI/2016 adalah bahwa alat bukti elektronik masih bisa digunakan dalam peradilan pidana hanya saja ada pembatasan mengenai cara perolehan dan pengajuannya sebagai alat bukti elektronik pada proses persidangan. Pengaturan mengenai batasan dalam pengajuan dan caramemperolehan alat bukti elektronik sudah sangat tepat untuk menghindari perekaman gambar dan penyadapan suara secara liar dan juga unlawfull legal evidence, yang bertujuan untuk melindungi privasi masyarakat.

\section{DAFTAR PUSTAKA}

Aburaera, Sukarno, dkk, 2014, Filsafat Hukum Teori dan Praktik, Kencana Prenada Group, Jakarta.

Adhi, I Putu Krisna dan Nurmawati, Made, Legalitas Personal Chat Pada Sosial Media Sebagai Alat Bukti di Pengadilan, Fakultas Hukum Universitas Udayana, ojs.unud.ac.id/index. $\mathrm{php/kerthawicara/article/}$ view/21305/14077, diakses pada Tahun 2016.
Ali, M. Hata dan Amran Suadi, 2014, Sistem Pengawasan Badan Peradilan Indonesia, PT. Raja Grafindo Persada, Jakarta.

Arenson,KennethJ., danMirkoBagaric, 2005, Rules of Evidence in Australia Text and Cases, Lexis NexisButterwordths, Australia.

Asikin, Zainal, 2013, Mengenal Filsafat Hukum, Pustaka Reka Cipta, Bandung.

Azhary, Muhammad Tahir, 2004, Negara Hukum (Suatu Study tentang Prinsip-Prinsip Dlilihat dari Segi Hukum Islam, Implementasinya Pada Periode Negara Madinah dan Masa Kini), Penerbit Bulan Bintang, Jakarta.

Darmodiharjo, Darji dan Shidartha, 2006, Pokok-Pokok Filsafat Hukum, Perbit PT Gramedia, Jakarta.

Fuady, Munir, 2011, Teori Negara Hukum Modern Rechtstaat, PT. Refika Aditama, Bandung.

Garner, Bryann A., 2009, Black's Law Dictionary, Ninth Edition, West Publishing Co, Texas.

Hamzah, Andi, 2008, Hukum Acara Pidana di Indonesia, Sinar grafika, Jakarta.

Hiariej, Eddy O.S., 2012, Teori dan Hukum Pembuktian, Penerbit Erlangga, Jakarta.

Jodi. S., dan EdyHerdianto, Alat Bukti Elektronik Sebagai Alat Bukti di Persidangan dalam Hukum Acara Pidana, jurnal.hukum. uns.ac.id/index.php/verstek/ 
article/view/703, diakses pada Tahun 2015.

Marwan, M., dan Jimmy P., 2009,

Kamus Hukum, penerbit Reality Publisher, Surabaya.

Mulyadi, Lilik, 2007, Pembalikan

Beban Pembuktian Tindak

Pidana Korupsi, Alumni,

Bandung.

Packer, Herbert L., 1968, The Limit

of Criminal Sanction, Stanford

University Press, California.

Panggaribuan, Ruhut M.P., 2013,

Hukum Acara Pidana Surat

Resmi Advokat di Pengadilan,

Penerbit Papas Sinar Sinanti, Jakarta.

Siahaan, Maruarar, 2015, Hukum

Acara Mahkamah Konstitusi

Republik Indonesia, Sinar

Grafika, Jakarta.

Soerjono S. \& Sri M., 2012, Penelitian

Hukum Normatif.Suatu Tinjauan

Singkat, Cet. Ke-14, PT. raja

Grafindo, Jakarta.

Prasetyo, Teguh dan Abdul Halim

Barkatullah, 2014, Fisafat,

Teori, dan Ilmu Hukum, PT Raja

Grafindo Persada, Jakarta.

Sunaryo, Sidik, 2004, Sistem Peradilan

Pidana, Penerbit Universitas

Muhamadiyah Malang, Malang.

Wahyudi, Johan, Dokumen elektronik

Sebagai Alat Bukti Papa

Pembuktian di Pengadilan,

Jurnal Fakultas Hukum

Universitas Airlangga Surabaya,

Volume XVII No. 2 Tahun 2012

Edisi Mei.

\section{PERATURAN \\ PERUNDANG-UNDANGAN}

Undang-Undang Dasar Negara Republik Indonesia Tahun 1945.

Undang-Undang Nomor 8 tahun 1981 tentang Hukum Acara Pidana. Lembaran Negara Republik Indonesia Nomor 4607.

Undang-undang Nomor 48 Tahun 2009 tentang Kekuasaan Kehakiman. Lembaran Negara Republik Indonesia Nomor 5076.

Undang-Undang Nomor 20 Tahun 2001 tentang Pemberantasan Tindak Pidana Korupsi. Lembaran Negara Republik Indonesia Nomor 4150.

Undang-undang Nomor 15 Tahun 2002 tentang Tindak Pidana Pencucian Uang.Lembaran Negara Republik Indonesia Nomor 4324.

Undang-Undang Nomor 15 Tahun 2003 tentang Pemberantasan Tindak Pidana Terorisme. Lembaran Negara Republik Indonesia Nomor 4284.

Undang-Undang Nomor 11 Tahun 2008 tentang Informasi dan Transaksi Elektronik. Lembaran Negara Republik Indonesia Nomor 4843. 